https://doi.org/10.35339/msz.2019.82.01.02

УДК 611.817.1:57.086:517:530.191

\author{
Н.І. Мар’єнко, О.Ю. Степаненко
}

Харківський національний медччний університет

\title{
ФРАКТАЛЬНИЙ АНАЛІЗ ЯК МОРФОМЕТРИЧНИЙ МЕТОД У МОРФОЛОГІЇ: СПОСІБ ДИЛАТАЦІЇ ПІКСЕЛІВ ПРИ ДОСЛІДЖЕННІ ЦИФРОВИХ ЗОБРАЖЕНЬ АНАТОМІЧНИХ СТРУКТУР
}

\begin{abstract}
Розроблено метод дилатації пікселів для розрахунку фрактального індексу мозочка людини за даними магнітно-резонансної томографії. Для дослідження використовують фрагмент цифрового зображення (томограми) мозочка. Зображення калібрують, його фрагмент копіюють у програму Adobe Photoshop CS5, де створюють окреме цифрове зображення з розмірами та роздільною здатністю $2^{\mathrm{n}}$ пікселів на дюйм, де $\mathrm{n}$ - кількість етапів підрахунку фрактального індексу. Зображення контрастують і поетапно підраховують фонові, «порожні» та «заповнені» пікселі, що містять фрагменти досліджуваної структури. На кожному етапі вчетверо збільшують розмір одного пікселя i, таким чином, удвічі зменшують роздільну здатність зображення (із 64 пікселів на дюйм до 32, 16, 8, 4 та 2 пікселів на дюйм). За кількістю пікселів, що містять фрагменти досліджуваної структури, і розмірами пікселя відносно загальної площі зображення (box size) обчислюють фрактальний індекс мозочка.
\end{abstract}

Ключові слова: головний мозок, мозочок, фрактальний аналіз, фрактальний індекс, дилатація пікселів.

Вступ

Морфометрія наразі є обов'язковою частиною майже всіх морфологічних досліджень. Однак багато структур організму людини і тварин мають складнішу просторову організацію, яку неможливо оцінити традиційними морфометричними методами. Це - об'єкти 3 розгалуженою структурою. Їх уважають $\kappa в a$ зифрактальними, які за властивостями наближені до фракталів. Фракталом є структура, для якої характерні самоподібність і самоповторюваність на різних рівнях організації: частини структури повністю або частково повторюють цю структуру в цілому $[1,2]$. Для оцінювання складності просторової організації квазифрактальних структур, ступеня їхньої розгалуженості, отже, ступеня заповнення простору цією структурою й використовують фрактальний аналіз. Показником, що визначається при цьому методі морфометрії, $\epsilon$ фрактальний індекс. Цей показник варіює від 1 до 2. Фрактальний аналіз застосовують для дослідження білої і сірої речовини головного мозку, нейронів, судинної мережі [3-7] та інших структур.

У сучасних медико-біологічних дослідженнях використовують різні способи фрактального аналізу, серед яких найпростішими й найбільш зручними в застосуванні $є$ способи підрахунку комірок (box counting) та $\partial u$ латаиїі пікселів (pixel dilatation) [3-8].

До квазифрактальних структур належать мозочок людини, його розгалужені біла речовина й кора. Кількість робіт, що стосуються фрактального аналізу мозочка, $є$ невеликою. Досліджено тривимірну фрактальну розмір-

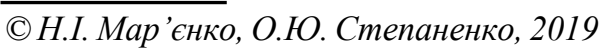


ність скелетованої білої речовини мозочка модифікованим методом дилатації пікселів [8], визначено тривимірний фрактальний індекс білої та сірої речовини мозочка [9]. Крім того, існують дослідження томограм мозочка в нормі та за синдрому Арнольда-Кіарі методом підрахунку комірок $[10,11]$.

У нашому попередньому дослідженні було розроблено авторську модифікацію методу підрахунку комірок (box counting) та адаптовано їі застосування для визначення фрактального індексу білої речовини мозочка під час секційних досліджень [12]. Проведено фрактальний аналіз білої речовини черв'яка й півкуль мозочка [13]. Метод підрахунку комірок може бути застосований для фрактального аналізу томограм мозочка, проте рутинність цього методу й невисока роздільна здатність цифрових зображень томограм мозочка спонукали нас до розробки нової модифікації фрактального аналізу способом дилатації пікселів.

Мета даного дослідження - розробка оригінальної модифікації способу дилатації пікселів для розрахунку фрактального індексу мозочка людини за даними морфометрії магнітно-резонансних томограм.

\section{Матеріал і методи}

Як об'єкт дослідження нами був обраний мозочок людини, біла речовина якого має фрактальні властивості [8-13]. Для розробки методики використані магнітно-резонансні томограми головного мозку, отримані за допомогою магнітно-резонансного томографа Siemens Magneton Concerto (ФРГ) зі значенням магнітної індукції 1,5 Тл у режимах Т1 i T2. Для дослідження використані серединні сагітальні томографічні зрізи головного мозку, що містять зріз черв'яка мозочка.

Методика складається 3 таких етапів. У програмі для перегляду томограм Syngo Fast View калібрують зображення та визначають ділянку для подальшого дослідження (puc. 1, a1, б1). Ділянка повинна мати форму квадрата; досліджувана структура - повністю розміщуватись у площі квадрата та вписуватись у його сторони.

У програмі Adobe Photoshop CS5 заздалегідь створюють окреме цифрове зображення (рамку) розміром $1 \times 1$ дюйм $\left(1\right.$ дюйм $\left.{ }^{2}\right)$ iз кольоровим режимом у градаиія х сірого, у яку копіюють фрагмент зображення, що містить досліджувану структуру. Усі подальші етапи роботи з иифровим зображенням проводять у програмі Adobe Photoshop.

Отримане зображення зберігають із роздільною здатністю 64 пікселі на дюйм, отже, розміри цього зображення в пікселях (64×64 пікселі) тотожні роздільній здатності зображення (64 пікселі на дюйм).

Для подальшого аналізу потрібно видалити структури, які не будуть досліджувати, залишивши на зображенні тільки досліджувану структуру і фон. Для цього всі інші об'єкти забарвлюють у колір фону (чорний - у режимі $\mathrm{T} 1$, білий - у режимі T2), залишаючи без змін ділянку, яка містить досліджувану структуру (рuc. 1, a3, 63).

Наступний етап фрактального аналізу автоматизований підрахунок пікселів, що містять досліджувану структуру. Для його проведення необхідно максимально відокремити досліджувану структуру від фону. Зображення 3 півтонового перетворюють у бінарне таке, що містить пікселі лише чорного (зі значенням яскравості 0) і білого (із яскравістю 255) кольорів. Контрастування проводять за допомогою інструмента «Поріг» програми Adobe Photoshop CS5: усі пікселі у градаціях сірого, темніші від заданого порогового значення, забарвлюються в чорний колір, світлішіу білий (рис. 1, а3, б3). Після контрастування в режимі T1 пікселі, що відповідають ділянці досліджуваної структури, забарвлюються білим кольором, фон - чорним; у режимі Т2, навпаки, досліджувана структура чорного кольору, а фон - білого. Для дослідження томограм у режимах Т1 і Т2 оптимальним пороговим значенням $\epsilon$ емпіричне значення яскравості 100, яке дозволяє визначити зовнішній контур часточок мозочка й міжчасточкові щілини, тобто контрастована ділянка відповідає тканині мозочка в цілому.

Подальшим етапом розрахунку фрактального індексу є власне морфометричне дослідження (рис. 2). За допомогою інструмента «Гістограма» підраховують пікселі: визначають загальну кількість пікселів (Р) та кількість білих, «порожніх» пікселів $\left(\mathrm{P}_{0}\right)$, що мають значення яскравості 255. Потім визначають кількість заповнених пікселів $\left(\mathrm{P}_{1}\right)$, що містять досліджувану структуру, як різнищю загальної кількості пікселів та порожніх пікселів $\left(\mathrm{P}_{1}=\mathrm{P}-\mathrm{P}_{0}\right)$. 


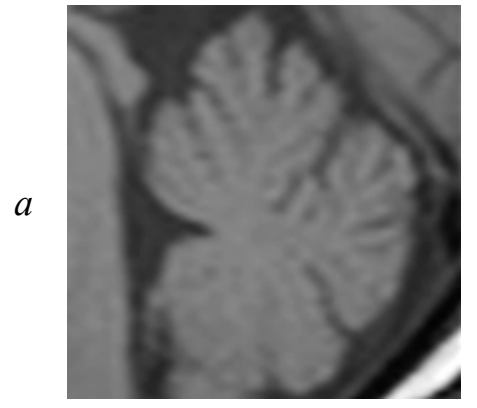

1

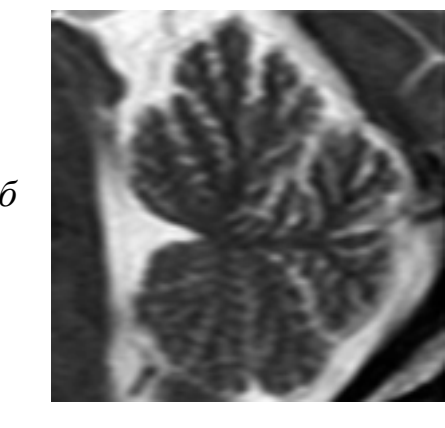

1

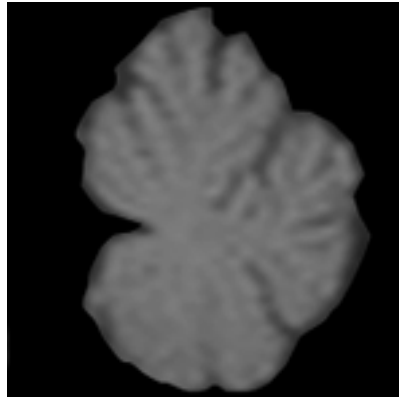

2

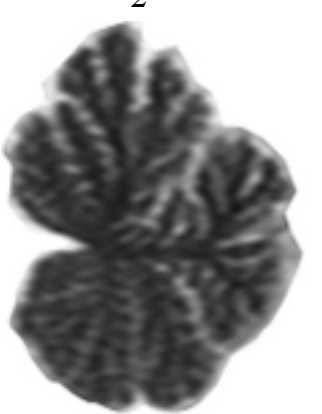

2

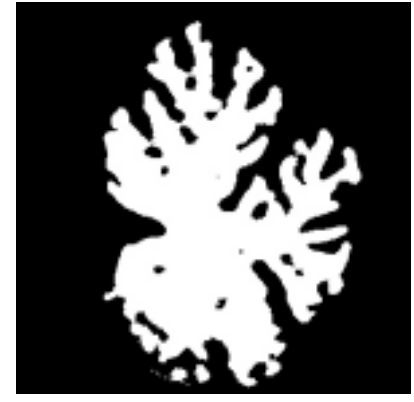

3

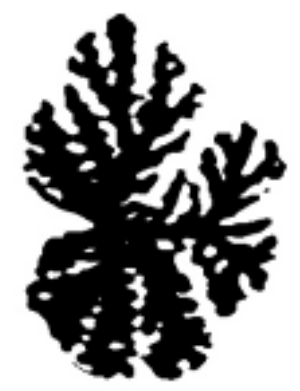

3

Рис. 1. Етапи підготовки цифрового зображення (МР-томограми мозочка людини в режимах

Т1 (a) і Т2 (б)) для морфометричного дослідження: 1 - вихідне зображення мозочка;

2 - виділений серединний сагітальний зріз мозочка; 3 - контрастування arbor vitae, поріг 100

Дослідження виконують поетапно. На першому етапі проводять підрахунок фонових (білих) та заповнених (чорних) пікселів на вихідному зображенні, що містить $64 \times 64$ пікселі (puc. 2, a).

На другому етапі морфометричного дослідження розмір кожного пікселя збільшують учетверо, зменшуючи вдвічі роздільну здатність зображення (із 64 до 32 пікселів на дюйм). При цьому кількість пікселів зменшується вчетверо (із $64 \times 64$ до $32 \times 32$ ), зображення «розмивається», а площа зображення, яку охоплює один піксель, відповідно, зростає в чотири рази, тобто відбувається розщирення (дилатація) пікселів.

Унаслідок цього кожен піксель на даному етапі має значення яскравості, що є середнім чотирьох пікселів, які охоплювали цю ділянку зображення на попередньому етапі (будемо вважати такі пікселі «розширеними», або дилатованими): білими залишаються лише ті дилатовані пікселі, які відповідають чотирьом білим, фоновим пікселям із попереднього етапу; чорними - дилатовані пікселі, які відповідають чотирьом чорним пікселям із попереднього етапу, які містили фрагменти досліджуваної структури. При цьому деякі дилатовані пікселі, які зараз охоплюють як ділянки $з$ до- сліджуваною структурою, так і фонові ділянки (отже, на попередньому етапі містили й білі, і чорні пікселі), забарвлюються в різні відтінки сірого, оскільки мають середнє значення яскравості пікселів вихідного зображення. Такі сірі пікселі вважають заповненими.

На третьому та подальших етапах процедуру обробки зображення повторюють. Розміри зображення в пікселях становлять $16 \times 16$, $8 \times 8,4 \times 4$ та $2 \times 2$ пікселі, а роздільна здатність 16, 8, 4 та 2 пікселі на дюйм відповідно. Дані заносять у таблицю (табл. 1).

Якщо на останніх етапах підрахунку вже немає «порожніх» пікселів (як на п'ятому й шостому етапах даного дослідження, puc. 2), результати підрахунку цих етапів до подальшого аналізу не включають.

Крім того, для підрахунку фрактального індексу визначають показник box size - відношення сторони пікселя до сторони квадрата всього зображення. Вох size встановлюють залежно від роздільної здатності зображення: на першому етапі він дорівнює $1 / 64$, на другому $-1 / 32$, на подальших етапах $-1 / 16,1 / 8$, 1/4 та $1 / 2$ відповідно.

Після цього обчислюють два показники: натуральний логарифм числа, зворотного box size $(\ln (1 /$ box size $))$, та натуральний логарифм 


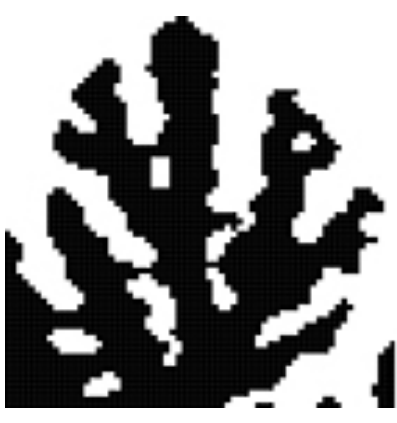

$a$

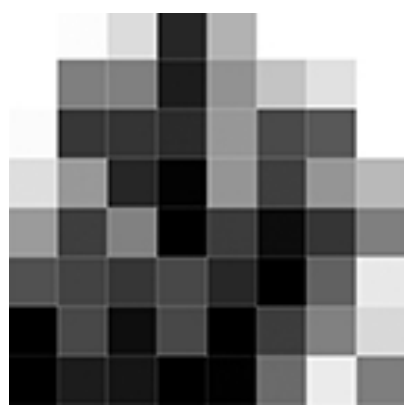

2

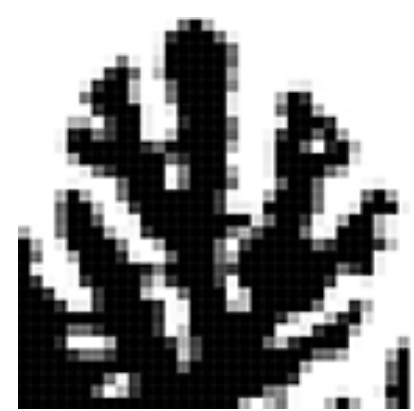

6

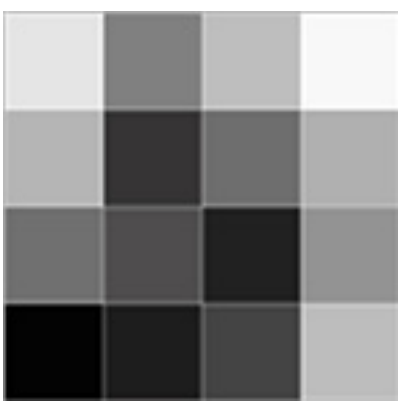

$\partial$

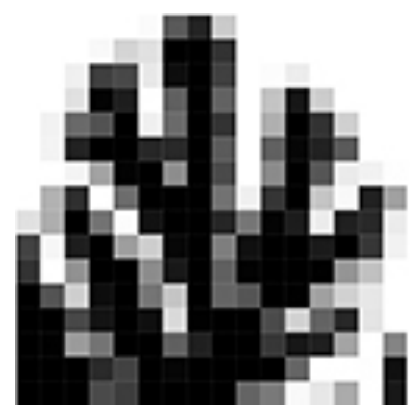

$B$

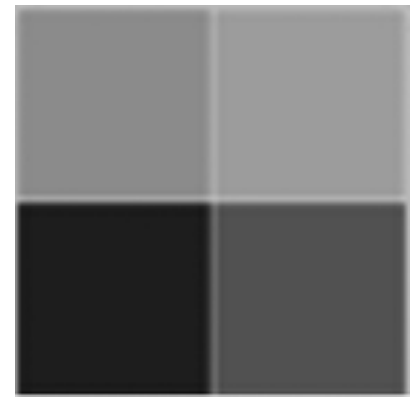

$e$

Рис. 2. Етапи морфометрії за фрактального аналізу способом дилатації пікселів: $a$ - box size $=64$; $\sigma-$ box size $=32 ; \beta-$ box size $=16 ; 2-$ box size $=8 ; \partial-$ box size $=4 ; e-$ box size $=2$

Таблиия 1. Морфометричні дані підрахунку фрактального індексу мозочка способом дилатації пікселів

\begin{tabular}{|c|c|c|c|c|c|}
\hline \multirow{2}{*}{$\begin{array}{c}\text { Етап } \\
\text { дослідження }\end{array}$} & \multirow{2}{*}{$\begin{array}{c}\text { Розмір зображення, } \\
\text { пікселів }\end{array}$} & \multirow[b]{2}{*}{$\begin{array}{c}\text { Роздільна здатність, } \\
\text { пікселів на дюйм }\end{array}$} & \multicolumn{3}{|c|}{ Кількість пікселів } \\
\hline & & & загальна, P & $\begin{array}{c}\text { порожніх, } \\
\mathrm{P}_{0}\end{array}$ & $\begin{array}{c}\text { заповнених, } \\
\mathrm{P}_{1}\end{array}$ \\
\hline $1-и ̆$ & $64 \times 64$ & 64 & 4096 & 2079 & 2017 \\
\hline 2-й & $32 \times 32$ & 32 & 1024 & 344 & 680 \\
\hline $3-и ̆$ & $16 \times 16$ & 26 & 256 & 56 & 200 \\
\hline 4-й & $8 \times 8$ & 8 & 64 & 7 & 57 \\
\hline 5-й & $4 \times 4$ & 4 & 16 & 0 & 16 \\
\hline 6-й & $2 \times 2$ & 2 & 4 & 0 & 4 \\
\hline
\end{tabular}

числа, що відповідає кількості заповнених пікселів $\left(\ln \left(\mathrm{P}_{1}\right)\right)$ (табл. 2).

Визначають лінійну залежність $\ln (\mathrm{P})$ від $\ln (1 /$ box size) за рівнянням лінійної регресії: фрактальний індекс дорівнює коефіцієнту нахилу прямої регресії відносно осі абсцис (puc. 3).

\section{Результати та їх обговорення}

Рівняння лінійної регресії на рис. 3 має вигляд $y=1,7201 x+0,503$, отже, фрактальний індекс мозочка 3 прикладу дорівнює 1,7201. Наведений у роботі алгоритм дозволяє роз- раховувати фрактальний індекс, використовуючи власні модулі програм обробки цифрових зображень. Крім програми Syngo Fast View можуть бути використані й інші програми для перегляду й калібрування томограм. Для подальшого аналізу зображень ми використовували програму Adobe Photoshop CS5, але крім неї можуть бути використані й інші графічні редактори з параметрами, рівноцінними програмі Adobe Photoshop CS5, або такими, що їх перевершують.

Таблиия 2. Математичні й морфометричні дані для розрахунку фрактального індексу

\begin{tabular}{c|c|c|c|c}
\hline Етап дослідження & Box size & Кількість заповнених пікселів, $\mathrm{P}_{1}$ & $\ln (1 /$ box size $)$ & $\ln \left(\mathrm{P}_{1}\right)$ \\
\hline $1-\breve{и ̆}$ & $1 / 64$ & 2017 & 4,16 & 7,61 \\
$2-\breve{и ̆}$ & $1 / 32$ & 680 & 3,47 & 6,52 \\
$3-\breve{и ̆}$ & $1 / 16$ & 200 & 2,77 & 5,30 \\
$4-\breve{и ̆}$ & $1 / 8$ & 57 & 2,08 & 4,04 \\
\hline
\end{tabular}




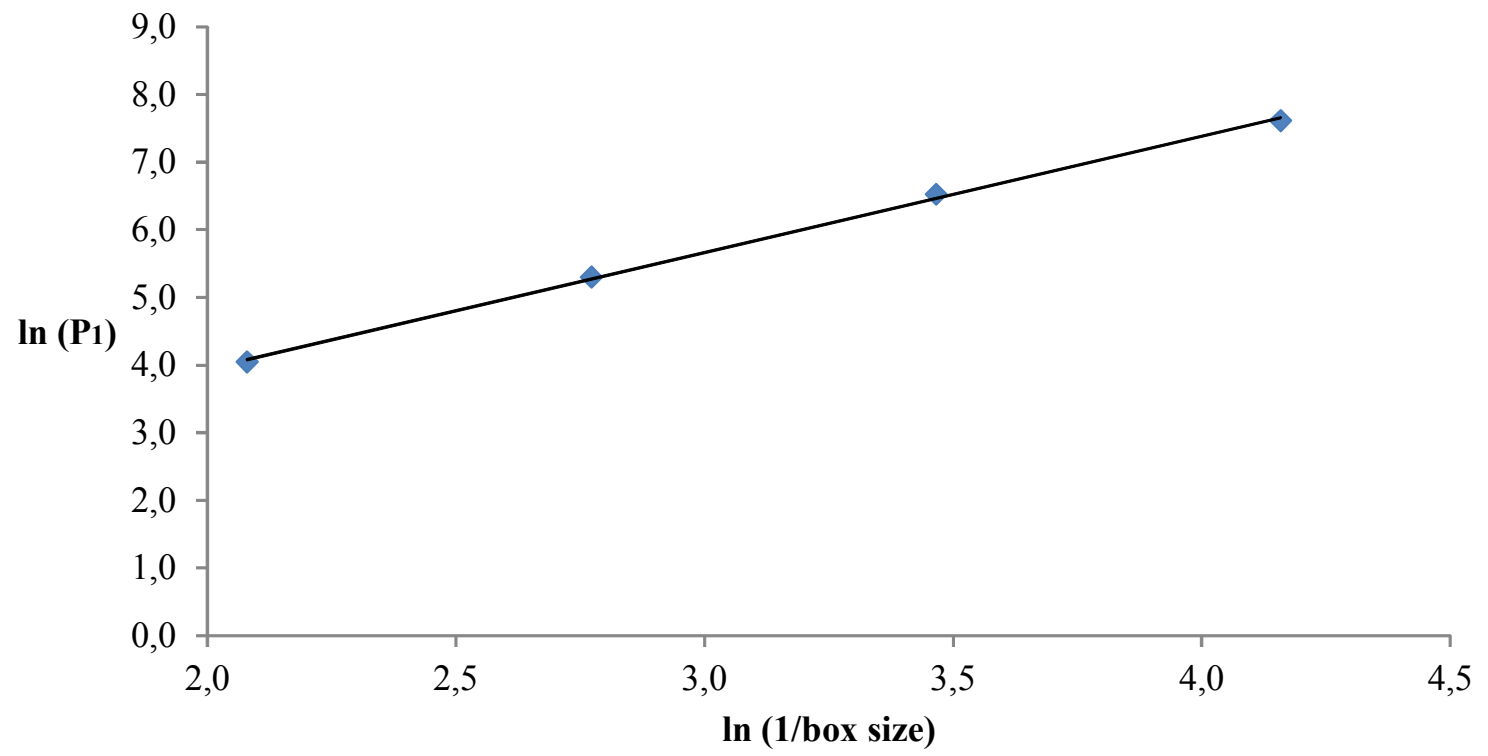

Рис. 3. Графік лінійної залежності при підрахунку фрактального індексу білої речовини мозочка

Розміри цифрового зображення, що досліджується, визначають розмірами досліджуваної структури на вихідному зображенні, $n p u$ цьому кількість пікселів кожної сторони квадрата має бути $2^{n}$. У даній формулі показник степеня $\mathrm{n}$ визначає кількість морфометричних етапів підрахунку фрактального індексу (табл. 1): чим більше пікселів має зображення, тим більше етапів включатиме фрактальний аналіз. За нашими даними, для дослідження окремих часточок і ділянок мозочка на томограмах (як і для більшості гістологічних і мікроанатомічних структур) оптимальним розміром квадрата зображення $\epsilon$ 64×64 пікселі, що передбачає шість етапів $\left(64=2^{6}\right)$ морфометричного дослідження. Оптимальним розміром квадрата для дослідження серединного сагітального зрізу мозочка в цілому є 128×128 пікселів, що потребує проведення семи $\left(128=2^{7}\right)$ етапів дослідження. Кількість етапів морфометрії обмежується роздільною здатністю вихідного зображення, оскільки саме вона визначає кількість пікселів квадрата дослідження, яка зі свого боку зумовлює стартову роздільну здатність зображення у програмі Adobe Photoshop. При дослідженні серединного сагітального зрізу мозочка в цілому встановлюється стартова роздільна здатність 64 або 128 пікселів на дюйм; при дослідженні окремих часточок мозочка 64 пікселі на дюйм.
Роздільна здатність вихідного зображення суттєво впливає на точність результату: чим вона більша, тим меншу площу досліджуваної структури охоплюватиме один піксель, отже, тим вищою буде точність отриманих результатів, оскільки зображення більш контрастне.

Для спрощення підрахунку доцільно, щоб розміри сторони квадрата цифрового зображення у програмі Adobe Photoshop у пікселях та роздільна здатність були тотожніми. Це можливо, якщо метричні розміри сторони квадрата цифрового зображення (рамки) $1 \times 1$ дюйм.

Науковою роботою, що включає застосування способу дилатації пікселів для фрактального аналізу МРТ мозочка, найбільш близькою за методологією до нашого дослідження, $\epsilon$ [8], у якій J.Z. Liu та ін. встановлювали тривимірний фрактальний індекс. Для його визначення було використано корональні зрізи МРТ мозочка, що мали досить низьку роздільну здатність (1 піксель $=1$ мм $\left.^{2}\right)$. Спочатку поетапно розширювали розміри пікселів. Потім для кожного з етапів проводили скелетонування мозочка: створювали лінії, що відповідають напрямку основних гілок мозочка. Обчислювали кількість пікселів скелетованих ліній та за формулою визначали фрактальний індекс, який у мозочка становив $2,57 \pm 0,01$.

Методика підрахунку фрактального індексу, описана у [8], має досить суттєві від- 
мінності від запропонованої нами та інші підходи до фрактального аналізу мозочка як фрактальної структури.

По-перше, істотну роль в оцінюванні морфологічних особливостей мозочка відіграє площина зрізу, використана для аналізу. Звивини й борозни мозочка, а також пластинки білої речовини, що лежать в основі часточок мозочка, спрямовані в напрямку від однієї півкулі до другої. Ці структури на поперечному перерізі утворюють «дерево життя» мозочка. У зв'язку з цим будову даних структур доцільно досліджувати саме на поперечному перерізі-у площині, перпендикулярній напрямку звивин мозочка, а саме: серединній сагітальній та паралельних їй парасагітальних. У роботі J.Z. Liu та ін. використані томограми мозочка в корональних площинах, які є неінформативними.

По-друге, у роботі J.Z. Liu та ін. використано скелетонування: визначено лінії, що відповідають напрямку основних гілок, потім підраховано пікселі, що відповідають цим лініям. Таким чином, підраховували фрактальний індекс осьових ліній гілок білої речовини. У нашому дослідженні використовується контрастування для відділення досліджуваної структури від фону, що дозволяє дослідити тканину мозочка в цілому, а також окремо визначити фрактальний індекс сірої та білої речовини, ураховуючи найменші гілки та листки мозочка, що мають істотний вплив на фрактальний індекс мозочка, а їхні зміни можуть свідчити про особливості морфофункціонального стану мозочка.

По-третє, у дослідженні J.Z. Liu та ін. спочатку проводять дилатацію пікселів, а потім скелетонування зображення та підрахунок пікселів. Це зумовлює зменшення площі, яку займає досліджувана структура, під час дилатації пікселів, що своєю чергою призводить до завищення фрактального індексу. Уважаємо за необхідне виділення досліджуваної структури (iї контрастування) до дилатації пікселів для чіткого диференціювання фонових (порожніх) та заповнених пікселів на кожному етапі.

У дослідженні J.Z. Liu та ін. [8] роздільна здатність зображень була досить низькою (1 пік-

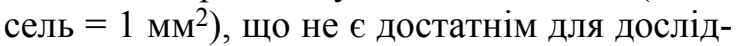
ження мікроанатомічних структур мозочка (листків, малих гілочок білої речовини), розміри яких часто не перевищують 1 мм.

На точність фрактального аналізу суттєво впливає роздільна здатність вихідного зображення (чим вища роздільна здатність, тим вища точність підрахунку), яка своєю чергою зумовлена значенням магнітної індукції магнітно-резонансного томографа. Чим вище це значення, тим вища якість цифрового зображення томограми, тим краще візуалізуються структури мозочка. Для застосування фрактального аналізу необхідне використання магнітно-резонансного томографа зі значенням магнітної індукції не менш за 1,5 Тл та роздільною здатністю отриманого цифрового зображення не менш ніж 72 пікселі на дюйм.

\section{Висновок}

Фрактальний аналіз способом дилатації пікселів може бути використаний для морфометричного дослідження магнітно-резонансних томограм головного мозку. Застосування фрактального аналізу дозволяє провести об'єктивне оцінювання морфофункціонального стану мозочка, що може бути використане для діагностики різних захворювань мозочка й інших структур центральної нервової системи. Значення фрактального індексу тканини мозочка в цілому в режимах Т1 і Т2 магнітнорезонансної томографії статистично значуще не відрізняються одне від одного, тому для дослідження можуть бути використані дані обох режимів магнітно-резонансної томографії. Різниця отриманих нами даних і даних інших дослідників обумовлена різницею методологічних підходів.

\section{Список літератури}

1. Mandelbrot B. B. Fractals: form, chance and dimension / B. B. Mandelbrot. - San Francisco : W. H. Freeman, 1977. -365 p.

2. Mandelbrot B. B. The fractal geometry of nature / B. B. Mandelbrot. - N.Y. : W. H. Freeman\&Co, 1983. - $468 \mathrm{p}$.

3. Farahibozorg S. Age- and sex-related variations in the brain white matter fractal dimension throughout adulthood: an MRI study / S. Farahibozorg, S. M. Hashemi-Golpayegani, J. Ashburner // Clin. Neuroradiol. 2015. - Vol. 25 (1). - P. 19-32. - DOI : 10.1007/s00062-013-0273-3. 
4. Automatic localization of cerebral cortical malformations using fractal analysis / A. De Luca, F. Arrigoni, R. Romaniello [et al.] // Phys. Med. Biol. - 2016. - Vol. 61 (16). - P. 6025-6040. DOI : $10.1088 / 0031-9155 / 61 / 16 / 6025$.

5. Fractal analysis of MRI data for the characterization of patients with schizophrenia and bipolar disorder / L. Squarcina, A. De Luca, M. Bellani [et al.] // Phys. Med. Biol. - 2015. - Vol. 60 (4) . P. 1697-1716. - DOI : 10.1088/0031-9155/60/4/1697.

6. Modified Richardson's method versus the box-counting method in neuroscience / I. Zaletel, D. Ristanovic, B. D. Stefanovic, N. Puskas // J. Neurosci. Methods. - 2015. - Vol. 242. - P. 93-96.

7. Ristanovic D. Fractal analysis of dendrite morphology using modified box-counting method / D. Ristanovic, B. D. Stefanovic, N. Puskas // Neurosci. Res. - 2014. - Vol. 84. - P. 64-67. DOI : 10.1016/j.neures.2014.04.005.

8. Liu J. Z. Fractal dimension in human cerebellum measured by magnetic resonance imaging / J. Z. Liu, L. D. Zhang, G. H. Yue // Biophys. J. - 2003. - Vol. 85 (6). - P. 4041-4046.

9. Fractal dimension analysis for quantifying cerebellar morphological change of multiple system atrophy of the cerebellar type (MSA-C) / Y. T. Wu, K. K. Shyu, C. W. Jao [et al.] // Neuroimage. - 2010. Vol. 49 (1). - P. 539-551. - DOI : 10.1016/j.neuroimage.2009.07.042.

10. Fractal analysis of MR images in patients with Chiari malformation: The importance of preprocessing / E. Akar, S. Kara, H. Akdemir, A. Kiris // Biomedical Signal Processing and Control. - 2017. - № 31. P. 63-70.

11. Fractal dimension analysis of cerebellum in Chiari malformation type I / E. Akar, S. Kara, H. Akdemir, A. Kiris // Computers in Biology and Medicine. - 2015. - № 64. - P. 179-186.

12. Степаненко А. Ю. Фрактальный анализ как метод морфометрического исследования белого вещества мозжечка человека / А. Ю. Степаненко, Н. И. Марьенко // Світ медицини та біології. 2016. - № 4 (58). - C. 127-130.

13. Степаненко А. Ю. Фрактальный анализ белого вещества мозжечка человека / А. Ю. Степаненко, Н. И. Марьенко // Світ медицини та біології. - 2017. - № 3 (61). - С. 145-149.

\section{References}

1. Mandelbrot B.B. (1977). Fractals - form, chance and dimension. San Francisco: W.H. Freeman, $365 \mathrm{p}$.

2. Mandelbrot B.B. (1983). The fractal geometry of nature. N.Y.: W.H. Freeman\&Co, 468 p.

3. Farahibozorg S., Hashemi-Golpayegani S.M., Ashburner J. (2015). Age- and sex-related variations in the brain white matter fractal dimension throughout adulthood: an MRI study. Clin. Neuroradiol., vol. 25 (1), pp. 19-32, DOI: 10.1007/s00062-013-0273-3.

4. De Luca A., Arrigoni F., Romaniello R., Triulzi F.M., Peruzzo D., Bertoldo A. (2016). Automatic localization of cerebral cortical malformations using fractal analysis. Phys. Med. Biol., vol. 61 (16), pp. 6025-6040, DOI: 10.1088/0031-9155/61/16/6025.

5. Squarcina L., De Luca A., Bellani M., Brambilla P., Turkheimer F.E., Bertoldo A. (2015). Fractal analysis of MRI data for the characterization of patients with schizophrenia and bipolar disorder. Phys. Med. Biol., vol. 60 (4), pp. 1697-1716, DOI: 10.1088/0031-9155/60/4/1697.

6. Zaletel I., Ristanovic D., Stefanovic B.D., Puskas N. (2015). Modified Richardson's method versus the box-counting method in neuroscience. J. Neurosci. Methods, vol. 242, pp. 93-96.

7. Ristanovic D., Stefanovic B.D., Puskas N. (2014). Fractal analysis of dendrite morphology using modified box-counting method. Neurosci. Res., vol. 84, pp. 64-67, DOI: 10.1016/j.neures.2014.04.005.

8. Liu J.Z., Zhang L.D., Yue G.H. (2003). Fractal dimension in human cerebellum measured by magnetic resonance imaging. Biophys. J., vol. 85 (6), pp. 4041-4046.

9. Wu Y.T., Shyu K.K., Jao C.W., Wang Z.Y., Soong B.W., Wu H.M., Wang P.S. (2010). Fractal dimension analysis for quantifying cerebellar morphological change of multiple system atrophy of the cerebellar type (MSA-C). Neuroimage, vol. 49 (1), pp. 539-551, DOI: 10.1016/j.neuroimage.2009.07.042.

10. Akar E., Kara S., Akdemir H., Kiris A. (2017). Fractal analysis of MR images in patients with Chiari malformation: The importance of preprocessing. Biomedical Signal Processing and Control, № 31, pp. 63-70.

11. Akar E., Kara S., Akdemir H., Kiris A. (2015). Fractal dimension analysis of cerebellum in Chiari malformation type I. Computers in Biology and Medicine, № 64, pp. 179-186. 
12. Stepanenko A.Yu., Maryenko N.I. (2016). Fraktalnyi analiz kak metod morfometricheskoho issledovaniia beloho veshchestva mozzhechka cheloveka [Fractal analysis as a method of morphometric study of the white matter of the cerebellum of a person]. Svit medytsyny ta biolohii - The World of Medicine and Biology, № 4 (58), pp. 127-130 [in Russian].

13. Stepanenko A.Yu., Maryenko N.I. (2017). Fraktalnyi analiz beloho veshchestva mozzhechka cheloveka [Fractal analysis of the human cerebellar white matter]. Svit medytsyny ta biolohii - The World of Medicine and Biology, № 3 (61), pp. 145-149 [in Russian].

\section{Н.И. Марьенко, А.Ю. Степаненко ФРАКТАЛЬНЫЙ АНАЛИЗ КАК МОРФОМЕТРИЧЕСКИЙ МЕТОД В МОРФОЛОГИИ: СПОСОБ ДИЛАТАЦИИ ПИКСЕЛЕЙ ПРИ ИССЛЕДОВАНИИ ЦИФРОВЫХ ИЗОБРАЖЕНИЙ АНАТОМИЧЕСКИХ СТРУКТУР}

Разработан метод дилатации пикселей для расчета фрактального индекса мозжечка человека по данным магнитно-резонансной томографии. Для исследования используют фрагмент цифрового изображения (томограммы) мозжечка. Изображение калибруют, его фрагмент копируют в программy Adobe Photoshop CS5, где создают отдельное цифровое изображение с размерами и разрешением $2^{\mathrm{n}}$ пикселей на дюйм, где $\mathrm{n}$ - количество этапов подсчета фрактального индекса. Изображение контрастируют и поэтапно подсчитывают фоновые, «пустые» и «заполненные» пиксели, содержащие фрагменты исследуемой структуры. На каждом этапе в четыре раза увеличивают размер одного пикселя и, таким образом, вдвое уменьшают разрешение изображения (с 64 пикселей на дюйм до $32,16,8,4$ и 2 пикселей на дюйм). По количеству пикселей, содержащих фрагменты исследуемой структуры, и размерам пикселя относительно общей площади изображения (box size) вычисляют фрактальный индекс мозжечка.

Ключевые слова: головной мозг, мозжечок, фрактальный анализ, фрактальный индекс, дилатация пикселей.

\section{N.I. Maryenko, O.Yu. Stepanenko FRACTAL ANALYSIS AS A MORPHOMETRIC METHOD IN MORPHOLOGY: A PIXEL DILATATION TECHNIQUE IN THE STUDY OF DIGITAL IMAGES OF ANATOMICAL STRUCTURES}

A pixel dilatation method for the calculation of fractal index of the human cerebellum was developed according to magnetic resonance imaging. A fragment of a digital image (tomogram) of the cerebellum is used for the study. The images are calibrated and fragments are copied into the program Adobe Photoshop CS5, where a single digital image is created; the size and resolution (pixels per inch) are calculated according to the formula $2^{\mathrm{n}}$, where $\mathrm{n}$ is the number of steps of the fractal dimension calculating. The image is contrasted and the background, blank, and filled pixels containing the fragments of the structure under study are counted step by step. The size of pixels is dilated at each stage and thus the image resolution is decreased (from 64 pixels per inch to $32,16,8,4$ and 2 pixels per inch). Taking into account the number of pixels containing fragments of the studied structure, and pixel sizes relative to the total image area (box size), the fractal dimension of the cerebellum is calculated.

Keywords: brain, cerebellum, fractal analysis, fractal dimension, pixel dilatation.

Надійшла 25.02.19

\section{Відомості про авторів}

Мар 'єнко Наталія Іванівна - кандидат медичних наук, асистент кафедри гістології, цитології та ембріології Харківського національного медичного університету.

Адреса: 61022, м. Харків, пр. Науки, 4, Харківський національний медичний університет.

Тел.: +38(095)140-50-88.

E-mail: maryenko.n@gmail.com.

ORCID: https://orcid.org/0000-0002-7980-7039.

Степаненко Олександр Юрійович - доктор медичних наук, доцент, завідувач кафедри гістології, цитології та ембріології Харківського національного медичного університету.

Адреса: 61022, м. Харків, пр. Науки, 4, Харківський національний медичний університет.

Тел.: +38(067)377-18-44.

E-mail: stepanenko@3g.ua.

ORCID: https://orcid.org/0000-0002-5686-0857. 